\title{
Effluent causes of the 'pigmented salmon syndrome' in wild adult Atlantic salmon Salmo salar from the River Don in Aberdeenshire
}

\author{
N. C. Everall ${ }^{1, *}$, C. G. Mitchell ${ }^{1}$, J. N. Robson ${ }^{2}$ \\ ' North East River Purification Board, Greyhope House, Greyhope Road, Aberdeen AB1 3RD, Scotland \\ ${ }^{2}$ The Scottish Office Agriculture and Fisheries Department, Marine Laboratory, PO Box 101, Victoria Road, Torry, Aberdeen \\ AB9 8DB, Scotland
}

\begin{abstract}
The effluent cause of a noninfectious hyperbilirubinaemia, or jaundice, in wild Don salmon was determined by exposing adult captive North Esk fish to environmentally relevant single and combined exposures of Donside discharges with control river water in situ. Adult North Esk salmon were chosen as test animals because they were physiologically pertinent, of different genetic origin or stock to Don fish, from a 'clean' river and successfully used in previous in situ riverine experiments. Experiments were conducted using a control group with 3 test groups of salmon exposed to individual or sequentially-combined industrial stream and untreated paper mill effluent for a test period of $4 \mathrm{wk}$. Sequential exposure of industrial stream followed by paper mill effluent produced haematological 'clinical profiles', i.e. a hyperbilirubinaemia in test North Esk salmon that was indistinguishable from wild Don fish. A combination of 2 types of effluent therefore appeared to be responsible for the noninfectious hyperbilirubinaemia reported in adult wild Don salmon during the previous decade. Chemical characterisation of the isolated effluents and the river are discussed with respect to known haemolytic agents from the toxicological literature.
\end{abstract}

\section{INTRODUCTION}

The River Don, Aberdeenshire, comprises the sixth most extensive river system in Scotland and supports a modest Atlantic salmon, sea trout and resident brown trout fishery. In recent years the Atlantic salmon fishery has been threatened by an epidemic of a noninfectious hyperbilirubinaemia or jaundice in adult wild fish. The pathophysiological condition of salmon suffering from the haemolytic syndrome has been well documented (Groman \& Miller, 1987).

Riverine isolation of potentially causative effluents was successful with in situ experiments using physiologically appropriate adult salmon taken from the North Esk (Everall et al. 1991). The field investigations (Everall et al. 1991) indicated that untreated paper mill and/or industrial stream effluents were the potential cause(s) of the noninfectious hyperbilirubinaemia in Don salmon. The present paper describes the results of

\footnotetext{
- Present address: Severn Trent Water plc, PO Box 51, Raynesway, Derby DE27JA, UK
}

further ecotoxicological investigations to determine the specific raw effluent cause of hyperbilirubinaemia in Don salmon using captive adult North Esk salmon as test fish.

\section{MATERIALS AND METHODS}

Adult wild Atlantic salmon Salmo salar L. (length 62 to $88 \mathrm{~cm}$, weight 2.5 to $5.0 \mathrm{~kg}$ ) were obtained via commercial netsmen from the River North Esk in Kincardinshire, Scotland, and transported to test sites on the River Don in Aberdeenshire. Staggered between February to April 1989, groups of salmon ( $n=5$ ) were held concurrently at control and industrial sites in a total of four $4 \mathrm{~m}^{3}$ tanks. Test salmon were exposed as independent groups for a period of ca $4 \mathrm{wk}$ to either: River Don water at the non-polluted control site (C); a 1 in 400 dilution of an industrial stream effluent with carbon-filtered Aberdeen tap water (IB); a 1 in 200 dilution of paper mill discharge with non-polluted River Don water (PM); or a 50:50 sequential exposure 
of IB followed by PM (IB/PM). Sixty percent of control salmon received a 'sham' transportation after $2 \mathrm{wk}$ to mimic any potential transport stress effects induced in fish moved between IB to PM sites during sequential effluent exposures. Adult salmon were maintained in $4 \mathrm{~m}^{3}$ fibreglass tanks which received approximately $151 \mathrm{~min}^{-1}$ of adjacent control river water, or in the case of IB-treated fish, ca $10 \mathrm{I} \mathrm{min}^{-1}$ of carbon-filtered tap water. Chemical analyses of Aberdeen tap water revealed no significant differences in the composition of essential trace elements (e.g. $\mathrm{Ca}^{2+}, \mathrm{Mg}^{2+}, \mathrm{K}^{+}, \mathrm{Na}^{+}$ or other trace inorganics, or heavy metals such as $\mathrm{Zn}^{2+}, \mathrm{Cu}^{2+}, \mathrm{Pb}^{2+}, \mathrm{Al}_{3}{ }^{+}, \mathrm{Mn}^{2+}, \mathrm{Fe}^{3+}, \mathrm{Cd}^{2+}, \mathrm{Ni}^{2+}$ ) from those found in reference River Don water (North East River Durification Board unpubl)

After 4 wk at the in situ test sites on the River Don, the fish were killed and ca $15 \mathrm{ml}$ of blood was removed immediately by caudal venipuncture using $5 \mathrm{ml}$ syringes fitted with 18 gauge needles heparinised with a 30 unit $\mathrm{ml}^{-1}$ solution of sodium heparin. All blood samples were placed in lithium heparinised vacutainers, thoroughly mixed and maintained at $4{ }^{\circ} \mathrm{C}$ prior to haematological determinations.

The majority of blood parameter measurements and plasma extractions were completed in the field at $4{ }^{\circ} \mathrm{C}$. Haematocrit was calculated immediately in triplicate on a minicentrifuge. Live total blood cell counts and mean erythrocyte volumes were determined within 1 to $4 \mathrm{~h}$ of sample collection using a Coulter Counter Model ZM and Channelyser C256. Cell counts $\left(\times 10^{6} \mathrm{~mm}^{-3}\right)$ were determined from triplicate samples with $10 \mu \mathrm{l}$ of whole blood added to $4.99 \mathrm{ml}$ of sterile filtered $(0.45 \mu \mathrm{m})$ Cortland saline in a sterile bijoux maintained at $4{ }^{\circ} \mathrm{C}$.

Whole blood haemoglobin content (g $100 \mathrm{ml}^{-1}$ ) was determined according to the quantitative colorimetric cyanomethaemoglobin assay (Blaxhall \& Daisley 1973). Calibration curves were prepared using a Sigma haemoglobin standard and results were expressed as the mean of triplicate subsample determinations. For differential red blood cell counts, triplicate blood smears were fixed in methanol for ca $20 \mathrm{~min}$, stained with combined May-Grunwald-Giemsa stain (Culling 1974) and examined under oil immersion on a Leitz photomicroscope. Results were recorded as the mean percentage of 3 counts and were expressed as the percentage of mature, immature, reticulocytic and pyknotic cells in a total count of 300 .

Blood was centrifuged immediately at $1500 \mathrm{rpm}$ for 5 min (ambient field temperature) at the low speed setting on a portable MSE Micro Centau Centrifuge. Plasma was then removed from the packed cells and stored at $4{ }^{\circ} \mathrm{C}$ prior to immediate analysis or further storage $\left(-80^{\circ} \mathrm{C}\right)$. Plasma from test salmon was subjected to Sequential Multiple Analysis via Computer
(Technicon SMAC II system) by the Department of Chemical Pathology at Aberdeen Royal Infirmary. The SMAC analyses determined plasma cuncentrations of albumin protein, alkaline phosphatase, glutamate oxaloacetate transaminase, calcium, bicarbonate creatinine, lactate dehydrogenase, potassium, sodium, total bilirubin, total cholesterol, total protein, urea and uric acid. Methods for plasma determinations were identical to those used in Everall et al. (1991).

Samples of paper mill effluent, industrial burn, test tank and River Don water were taken at regular intervals for characterisation of trace organic components. The samples from the paper mill effluent and the industrial burn were composite samples taken over a $24 \mathrm{~h}$ period. These samples $(n=21)$ were collected using an Epic $1011 \mathrm{~T}$ programmeable water sampler. Water samples $(n=21)$ from the test tank and river were collected in hand-held amber winchesters. All samples were frozen immediately $\left(-20^{\circ} \mathrm{C}\right)$ upon return to the laboratory. Following thawing, water samples were acidified ( $\mathrm{pH} 2$, conc. $\mathrm{HCl}$ ) and a recovery standard of 9,10-dichlorostearic acid added prior to extraction with dichloromethane $\left(3 \times 50 \mathrm{~cm}^{3}\right)$. After drying $\left(\mathrm{Na}_{2} \mathrm{SO}_{4}, 2 \mathrm{~g}\right)$, the solvent was evaporated (Buchi flask, $20^{\circ} \mathrm{C}$ ) and the total organic extract (TOE) transferred to a small amber vial $\left(2 \mathrm{~cm}^{3}\right)$ for storage at $4{ }^{\circ} \mathrm{C}$.

TOEs were methylated with diazomethane using the apparatus and technique described by Fales et al. (1973). Following methylation, diethyl ether and methanol were removed $\left(\mathrm{N}_{3}\right.$ blow down, $\left.10^{\circ} \mathrm{C}\right)$ and $1 \mathrm{~cm}^{3}$ of a 2,2,4-trimethylpentane solution containing 2 internal standards (2,4-dichlorobenzylhexyl ether and 2,4-dichlorobenzylhexadecyl ether) was added and the solution analysed by gas chromatography (GC) and gas chromatography-mass spectrometry (GC-MS).

Gas chromatographic analyses of the methylated TOE were performed on a Varian 3700 gas chromatograph equipped with an on-column injector (modified SGE OCI-2) and a flame ionisation detector (held at $320^{\circ} \mathrm{C}$ ). The column phase was CPSIL8CB (50 $\mathrm{m} \times 0.22 \mathrm{~mm}$ i.d.; Chrompack Ltd, Holland) and the column oven temperature programmed as follows: $110^{\circ} \mathrm{C}$ for $1 \min , 110$ to $300^{\circ} \mathrm{C}$ at $4^{\circ} \mathrm{C} \mathrm{min}{ }^{-1}$; and held at $300^{\circ} \mathrm{C}$ for $15 \mathrm{~min}$. The carrier gas was hydrogen at a flow rate of $2 \mathrm{~cm}^{3} \mathrm{~min}^{-1}$. Data was acquired with an Apple Ile microcomputer using an Adalab A/D interface card and modified 'Chromatochart' software. Individual resin acid methyesters (RAME) and other determinands were identified by comparison of their retention times with those of authentic standards. The quantitation of determinands was performed by comparison of the chromatographic peak areas of the determinands in the TOE with those of the authentic compounds.

Gas chromatographic-mass spectrometric analysis of the TOE was performed on a Finnigan 5100 GCMS. 
The column phase was DB $1(50 \mathrm{~m} \times 0.32 \mathrm{~mm}$ i.d.; $J$ and $\mathrm{W}$ Scientific) and the column oven temperature programme was identical to that used for GC analyses. The carrier gas was helium at a flow rate of $2 \mathrm{~cm}^{3} \mathrm{~min}^{-1}$. Data was acquired and processed using a super Incos 2300 data system. Chemical compounds in the TOE were identified by comparison of their mass spectra with those of authentic standards, library spectra and literature spectra.

Recovery experiments $(\times 5)$ were undertaken by spiking river water (2l) with a standard containing $500 \mathrm{ppb}$ of 2-(methylthio)benzothiazole and dehydroabietic acid. The spiked solutions were extracted and analysed using the same procedure as for samples. Results indicated average recoveries to be $91 \%$ for 2 (methylthio)benzothiazole and $78 \%$ for dehydroabietic acid.

\section{RESULTS}

Haematological measurements for experimental control (C), industrial stream (IB), untreated paper mill (PM) or sequentially combined IB/PM exposed salmon from the North Esk are shown in Table 1 as medians and ranges. Comparative data for wild hyperbilirubinaemic (yellow or jaundiced; Y) Don salmon are also shown in Table 1 . Previous examination of haematological measurements for wild (Groman \& Miller 1987) and experimental (Everall et al. 1991) salmon indicated non-parametric data sets. Box-and-whisker plots of the present experimental data also showed a similar skewed distribution of results. When required, non-parametric statistical analyses have therefore been applied to the present data sets.

A Kruskal-Wallis 1-way analysis of ranks was com-

Table 1. Salmo salar. Median (and range) of haematological parameters in experimental North Esk salmon $(\mathrm{n}=5)$ and $(\mathrm{Y})$ wild hyperbilirubinaemic Don salmon $(n=12)$. North Esk salmon exposed to: C, control; IB, industrial stream; PM, paper mill effluent; IB/PM, sequentially-combined industrial stream/paper mill effluents

\begin{tabular}{|c|c|c|c|c|c|c|}
\hline Parameter & Units & $\mathrm{C}$ & IB & PM & $\mathrm{IB} / \mathrm{PM}$ & $\mathrm{Y}$ \\
\hline $\begin{array}{l}\text { Haematocrit } \\
(\mathrm{Ht})\end{array}$ & $\%$ & $\begin{array}{c}47 \\
(36-50)\end{array}$ & $\begin{array}{c}49.5 \\
(31-64)\end{array}$ & $\begin{array}{c}30^{\circ} \\
(27-41)\end{array}$ & $\begin{array}{c}26^{\circ} \\
(22-34)\end{array}$ & $\begin{array}{l}34.4^{\circ} \\
(9-46)\end{array}$ \\
\hline $\begin{array}{l}\text { RBC count } \\
(\mathrm{RBC})\end{array}$ & $\times 10^{6} \mathrm{~mm}^{-3}$ & $\begin{array}{c}1.364 \\
(1.221-1.557)\end{array}$ & $\begin{array}{c}1.078^{\circ} \\
(0.947-1.373)\end{array}$ & $\begin{array}{c}0.881^{\circ} \\
(0.809-1.246)\end{array}$ & $\begin{array}{c}0.631^{\circ} \\
(0.433-0.981)\end{array}$ & $\begin{array}{c}0.78^{\circ} \\
(0.332-1.227)\end{array}$ \\
\hline $\begin{array}{l}\text { Immature } \\
\text { RBC count } \\
\text { (I-RBC) }\end{array}$ & $\%$ & $\begin{array}{c}1 \\
(0-1)\end{array}$ & $\begin{array}{c}7.9^{\circ} \\
(5.4-7.9)\end{array}$ & $\begin{array}{c}7.75^{\circ} \\
(1-16.8)\end{array}$ & $\begin{array}{c}15^{\circ} \\
(3-19)\end{array}$ & $\begin{array}{c}6.95^{\circ} \\
(0-58.1)\end{array}$ \\
\hline $\begin{array}{l}\text { Whole blood } \\
\text { haemoglobin } \\
\text { (Hb) }\end{array}$ & $\mathrm{gdl}^{-1}$ & $\begin{array}{c}12.8 \\
(11.47-14.75)\end{array}$ & $\begin{array}{c}10.44 \\
(8.43-14.75)\end{array}$ & $\begin{array}{c}7.16^{\circ} \\
(7.01-12.46)\end{array}$ & $\begin{array}{c}5.96^{\circ} \\
(5.43-9.46)\end{array}$ & $\begin{array}{c}7.62^{\circ} \\
(1.5-11.8)\end{array}$ \\
\hline $\begin{array}{l}\text { Mean RBC } \\
\text { volume } \\
\text { (MCV) }\end{array}$ & $\mathrm{fl}$ & $\begin{array}{c}233.8 \\
(227.4-246.5)\end{array}$ & $\begin{array}{c}259.2^{\circ} \\
(242.6-281)\end{array}$ & $\begin{array}{c}258.6^{*} \\
(218.3-276.1)\end{array}$ & $\begin{array}{c}262.7^{\bullet} \\
(255.2-317)\end{array}$ & $\begin{array}{c}278.4^{\circ} \\
(260.4-349.5)\end{array}$ \\
\hline $\begin{array}{l}\text { Plasma } \\
\text { potassium } \\
(\mathrm{K})\end{array}$ & $\mathrm{mmol} \mathrm{l} \mathrm{l}^{-1}$ & $\begin{array}{c}1.3 \\
(1-2)\end{array}$ & $\begin{array}{c}4^{*} \\
\left(1.2^{-}-5.9\right)\end{array}$ & $\begin{array}{c}4.4^{*} \\
(2.6-5)\end{array}$ & $\begin{array}{c}5.3^{\circ} \\
(4.6-15)\end{array}$ & $\begin{array}{c}2.8^{*} \\
(0.4-6.8)\end{array}$ \\
\hline $\begin{array}{l}\text { Plasma } \\
\text { sodium (Na) }\end{array}$ & $\mathrm{mmol} \mathrm{l}{ }^{-1}$ & $\begin{array}{c}143 \\
(122-148)\end{array}$ & $\begin{array}{c}128.5 \\
(90-158)\end{array}$ & $\begin{array}{c}138 \\
(120-143)\end{array}$ & $\begin{array}{c}130 \\
(93-152)\end{array}$ & $\begin{array}{c}151.5 \\
(109-163)\end{array}$ \\
\hline $\begin{array}{l}\text { Plasma LDH } \\
(\mathrm{LDH})\end{array}$ & units $1^{-1}$ & $\begin{array}{c}440 \\
(340-696)\end{array}$ & $\begin{array}{c}1404 \\
(93-2074)\end{array}$ & $\begin{array}{c}1528 \\
(233-3006)\end{array}$ & $\begin{array}{c}3132^{\circ} \\
(797-3528)\end{array}$ & $\begin{array}{c}1889^{\circ} \\
(875-16860)\end{array}$ \\
\hline $\begin{array}{l}\text { Plasma GOT } \\
\text { (GOT) }\end{array}$ & units $1^{-1}$ & $\begin{array}{c}876 \\
(830-1430)\end{array}$ & $\begin{array}{c}732 \\
(468-1769)\end{array}$ & $\begin{array}{c}1746 \\
(414-4032)\end{array}$ & $\begin{array}{c}3330 \\
(306-5508)\end{array}$ & $\begin{array}{c}1014 \\
(240-2880)\end{array}$ \\
\hline $\begin{array}{l}\text { Plasma AP } \\
\text { (AP) }\end{array}$ & units $l^{-1}$ & $\begin{array}{c}269 \\
(156-1051)\end{array}$ & $\begin{array}{c}294.5 \\
(188-900)\end{array}$ & $\begin{array}{c}182 \\
(119-239)\end{array}$ & $\begin{array}{c}104 \\
(35-474)\end{array}$ & $\begin{array}{c}430.5 \\
(32-2100)\end{array}$ \\
\hline $\begin{array}{l}\text { Plasma } \\
\text { cholesterol } \\
\text { (CHOL) }\end{array}$ & $\mathrm{mmol} \mathrm{l} \mathrm{l}^{-1}$ & $\begin{array}{c}17.3 \\
(10.2-18.5)\end{array}$ & $\begin{array}{c}9.8 \\
(8.1-16.7)\end{array}$ & $\begin{array}{c}4.7^{*} \\
(3.3-8.6)\end{array}$ & $\begin{array}{c}8.8^{\circ} \\
(3.2-13)\end{array}$ & $\begin{array}{c}7.7^{\circ} \\
(1.1-13.2)\end{array}$ \\
\hline $\begin{array}{l}\text { Plasma } \\
\text { bilirubin } \\
\text { (BIL) }\end{array}$ & $\mu \mathrm{mol} \mathrm{l} \mathrm{l}^{-1}$ & $\begin{array}{c}1 \\
(1-5)\end{array}$ & $\begin{array}{c}2 \\
(1-23)\end{array}$ & $\begin{array}{c}2.5 \\
(1-10)\end{array}$ & $\begin{array}{c}16^{\bullet} \\
(9-200)\end{array}$ & $\begin{array}{c}29^{\circ} \\
(4-98)\end{array}$ \\
\hline
\end{tabular}


puted for each haematological variate and the significant differences between effluent-exposed North Esk and wild yellow Don salmon from the control group are indicated.

The haematological variates which most strongly differentiated between groups were haematocrit $(\mathrm{Ht})$, red blood cell count (RBC), percentage immature red blood cell (IRBC), mean red blood cell volume (MCV), plasma potassium (K), lactate dehydrogenase (LDH), cholesterol (CHOL) and bilirubin (BIL). In all cases where significant differences were found, with the exception of plasma cholesterol, the largest difference in median values was between the control (C) and IB/ PM exposed North Esk salmon or yellow (Y) Don salmon.

'Clinical profiles' for median haematological variates from effluent-exposed salmon were compared with yellow Don fish in Fig. 1. The values were expressed as a percentage of the measurement in control salmon which is set at $100 \%$. Exposure to industrial stream effluent (IB) induced an erythropoietic effect in test salmon through elevated levels of immature erythrocytes. Raised haematocrit and erythrocyte swelling (MCV) in IB exposed salmon may have been precursive to slight haemolytic effects evident from RBC numbers or plasma potassium levels. Untreated paper mill effluent (PM) appeared to be responsible for the induction of a significant haemolytic anaemia or haemoglobinaemia in test salmon that was indistinguishable from yellow Don fish. However, the overall condition of a significant hyperbilirubinaemia only occurred in IB/ PM exposed North Esk salmon and wild yellow Don fish as shown in Fig. 1. IB/PM exposed salmon were indistinguishable from yellow Don fish in their significant haematological or 'clinical' profiles and $60 \%$ were identical in gross pathology (Everall et al. 1989). Gross pathology refers to bilirubin colouration of epithelial/ subepithelial tissues and necrotic tissue changes, e.g. liver damage. Four week exposures to the individual effluent exposures failed to produce a hyperbilirubinaemia in test salmon and controls showed no deleterious changes.

Analysis of the methylated extract of the untreated paper mill effluent by GC-MS revealed the presence of several different types of trace organic compounds of which the major components were diterpenoid (or resin) acids. A full list of the compounds identified together with their calculated concentrations (in $\mu \mathrm{g} \mathrm{l}^{-1}$ ) are recorded in Table 2. Untreated paper mill effluent was shown to contain in excess of $100 \mu \mathrm{g} \mathrm{I}^{-1}$ total diterpenoid acids; composed mainly of dehydroabietic acid (I; see Fig. 2) and 4 other minor isomers, pimaric (II), isopimaric (III), sandaracopimaric acid (IV) and abietic acid (V). Diterpenoid acids are natural components of conifer resins and are released to the process waters in elevated concentrations during paper pulp processing. Diterpenoid acids also present, at a concentration of $20 \mathrm{Mg} \mathrm{l}^{-1}$, in samples of river water collected
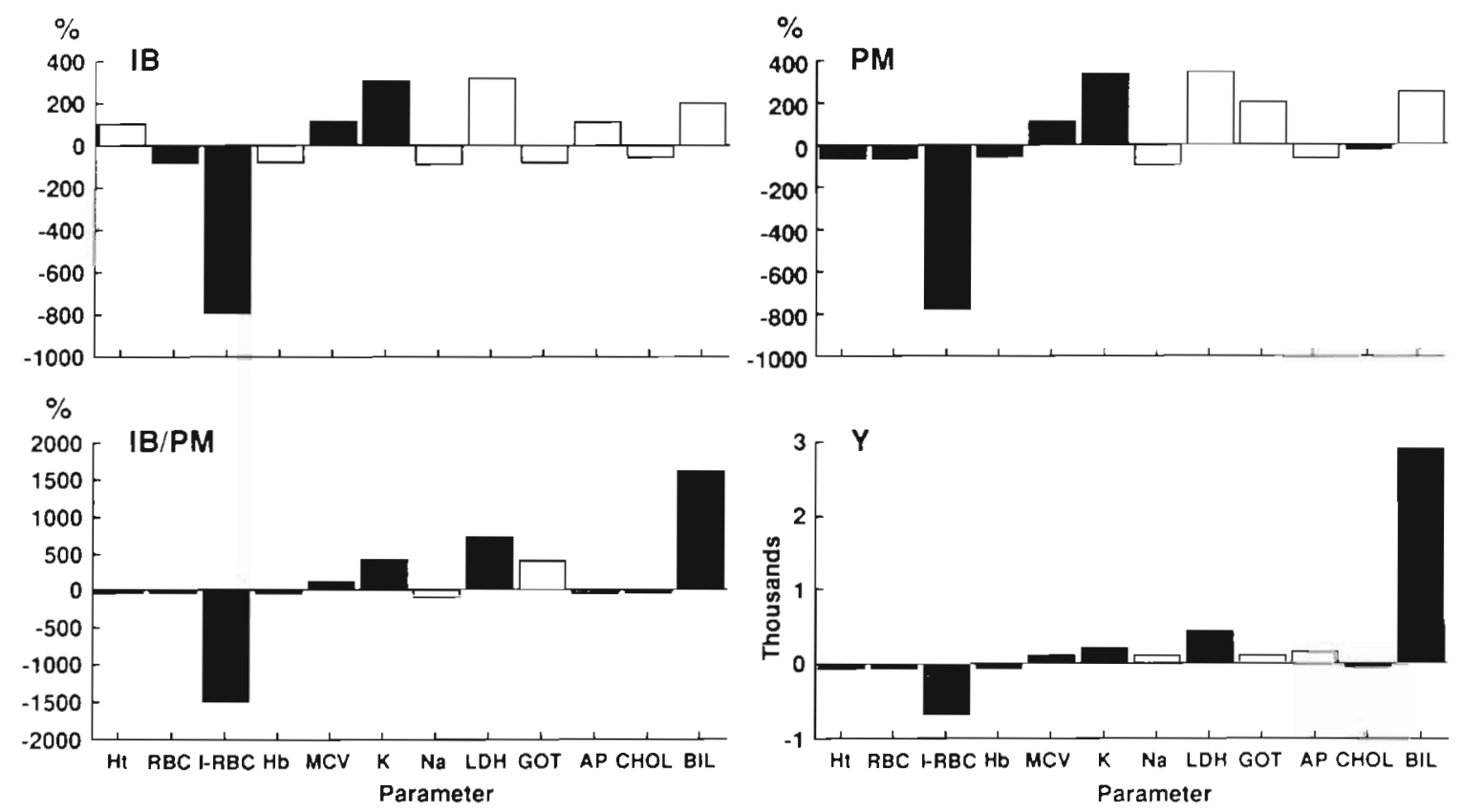

Fig. 1. Salmo salar. Haenâtological 'clinical profiles' in adult North Esk salmon exposed to industrial stream (IM), (PM) and sequentially-combined IB/PM effluents. Expenmental groups are compared with results for adult yellow Don salmon (Y). All values are expressed as a percentage of the result for control salmon which is set at $100 \%$. Solid bars indicate significance at $p \leq$ 0.05 and open bars represent only a trend (Kruskal-Wallis) 
Table 2. Concentrations ( $\mu \mathrm{g}^{-1}$ ) of the major trace organic compounds identified in the untreated effluent of a paper mill ${ }^{*}$ Roman numerals in parentheses refer to structures in Fig. 2. ND: concentration not determined

\begin{tabular}{|lc|}
\hline Compound & $\begin{array}{c}\text { Concentration } \\
\left(\mu \mathrm{g} \mathrm{l}^{-1}\right)\end{array}$ \\
\hline 2-(methylthio)benzothiazole & 10.94 \\
Stearic acid & 12.94 \\
Diterpenoid acids & \\
Pimaric acid (II) & 2.51 \\
Sandaracopimaric acid (IV) & 7.38 \\
Isopimaric acid (III) & 15.85 \\
Abietic acid (V) & 11.80 \\
Dehydroabietic acid (I) & 159.93 \\
$\quad$ Total & 197.47 \\
Trichlorofluoroethane & $\mathrm{ND}$ \\
Pentachlorophenol & $\mathrm{ND}$ \\
Carboxylic acids (C $-\mathrm{C}_{24}$ ) & $\mathrm{ND}$ \\
- 24 h composite sample (2 l) collected on 11 Sep 1989 \\
\hline
\end{tabular}

from a point $500 \mathrm{~m}$ downstream of the entry point of the paper mill effluent. The concentration of diterpenoid acids in the control river water, taken from a position above the mill, was below the detection limit of $0.1 \mu \mathrm{g}$ $\mathrm{I}^{-1}$. Concentrations of $30 \mu \mathrm{g} \mathrm{l^{-1 }}$ were recorded for diterpenoid acids in the test waters (PM and IB/PM). An examination of the primary effluents from other Donside paper mills revealed concentrations of diterpenoid
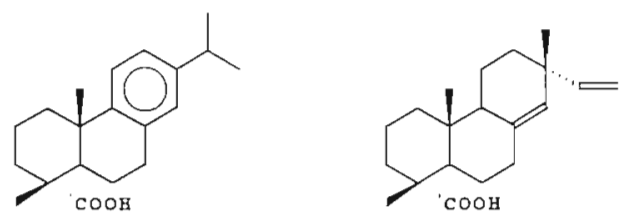

I
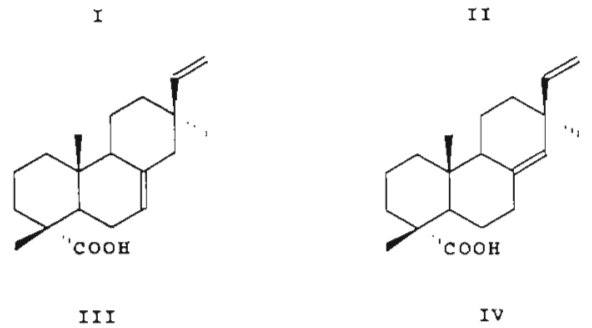

I I I

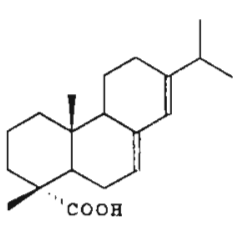

$\nabla$

Fig. 2. Chemical structures of the diterpenoid acids identified in paper mill effluents acids in excess of $400 \mu \mathrm{g} \mathrm{l^{-1 }}$. However, post-biological treatment of the primary effluent reduced the concentration of diterpenoid acids to less than $10 \mu \mathrm{g} \mathrm{l}^{-1}$ in the effluent entering the river. The other principle compounds identified in the paper mill effluent were benzothiazoles (VI) and low molecular weight chlorinated hydrocarbons, thought to be derived from biocides and cleaning solvents respectively.

Analysis of the industrial stream by GC-MS revealed the presence of petroleum-derived hydrocarbons, glycols, phthalates, alkyl-benzene sulphonamides and numerous other currently unidentified organic compounds. The petroleum hydrocarbons and glycols probably represent stormwater contamination of the industrial stream via airport run-off (aviation fuels, de-icers, etc.; Gay et al. 1987). Petroleum hydrocarbon contamination of the stream may also be derived from the activities (e.g. pipe cleansing) of numerous North Sea oil service companies located in this area. Of the other compounds identified in the stream, phthalate esters are used as plasticizers and are ubiquitous contaminants in water (Waldock 1983, Ritsema et al. 1989). Sources of the remaining contaminants are uncertain and investigations are continuing.

\section{DISCUSSION}

The artificial induction of a noninfectious hyperbilirubinaemia in test salmon identical to that reported in wild yellow fish from the River Don has enabled the isolation of the industrial effluents responsible for this syndrome. The majority of haematological disturbances recorded in PM or IB/PM effluent-exposed salmon and yellow Don fish are similar to those recorded in the literature for the effects of pulp and paper mill effluents on teleosts (Andersson 1987). However, previous studies were not reported to produce such gross haemolytic anaemia or hyperbilirubinaemia (i.e. jaundiced condition), as reported in the present study.

A severe haemoglobinaemia in PM and IB/PM effluent exposed salmon, and yellow Don fish was clear from significant reductions in total erythrocyte numbers and whole blood haemoglobin levels. Further evidence of haemolytic effects included an observed elevation of plasma potassium in IB, PM, IB/PM and yellow Don salmon which presumably resulted from leakage of intracellular potassium into surrounding body fluids through damaged cell membranes. Ionoregulatory mechanisms appeared incapable of compensating for this physiological disturbance. Plasma LDH also showed a marked elevation in IB/PM and yellow Don salmon when compared with control fish. $\mathrm{LDH}$ belongs to the non-plasma specific enzymes which are located within tissue cells and which have no 
known physiological function in plasma (Tietz 1976) This enzyme is present in the plasma in only low concentrations as the intact membranes are impermeable to such enzymes when the cells are metabolising normally. Following cell damage the membranes become permeable leading to an increase in enzyme activities within the extracellular fluids.

Increased mean cell volume in erythrocytes was most marked in IB/PM and yellow Don salmon but evident in all effluent-treated fish. Such disturbances may result from chemical insults specific to the individual, and therefore combined effluent exposures, or via catecholamine-induced changes in erythrocyte ultrastructure of stressed fish (Soivio \& Nikinmaa 1981). Cell swelling and raised haematocrit in IB salmon did not produce haemoglobinaemia but such changes may have been precursive to the haemolytic condition reported in IB/PM and yellow Don salmon, e.g. through intravascular lysis. The untreated paper mill effluent appeared therefore to contain agents capable of inducing haemolytic changes. Diterpenoid acids, present in the paper mill effluent in concentrations in excess of $400 \mu \mathrm{g} \mathrm{l}^{-1}$, have been proposed as 'active' haemolytic agents in previous studies on the toxicity of paper and pulp mill effluents (Andersson 1987, Härdig et al. 1988).

Previous investigations into bilirubinaemia induced by diterpenoid acids in sexually immature salmon (Kruzynski 1979) and rainbow trout (Matsoff \& Oikari 1987, Matsoff \& Nikinmaa 1988) suggested plasma bilirubin was mainly in the conjugated form. In the hyperbilirubinaemia observed in IB/PM and yellow Don salmon (Groman \& Miller 1987) the converse was true, e.g. in an IB/PM exposed salmon with a plasma bilirubin of ca $200 \mu \mathrm{mol} \mathrm{l}^{-1}$ only ca $3 \mu \mathrm{mol} \mathrm{l}^{-1}$ was conjugated. An inability to conjugate and excrete bilirubin in River Don salmon suffering from hyperbilirubinaemia may have resulted from the liver necrosis observed in PM, IB/PM and yellow Don salmon (Everall et al. 1989, Scotchford 1989) or from the inhibition of bilirubin UDP-glucuronyl transferase present in IB-exposed fish per se (Everall et al. 1989). Elevated serum levels of glutamate-oxaloacetate transaminase in PM, IB/PM and yellow Don salmon provided further evidence of mitochondrial liver damage (Nemcsók et al, 1981).

Sexually mature, non-feeding and migrating adult wild Atlantic salmon have been reported to undergo a generalised cachexia in fresh water (Everall et al. 1991). A natural metabolically altered cessation of hepatobiliary functions in spawning salmon may further increase susceptibility, reduce tolerance and inhibit recovery from bilirubinaemia following a toxic insult. The marked lipid depletion (e.g. cholesterol levels in PM, IB/PM and yellow Don salmon; Scotchford 1989) in adult wild Atlantic salmon exposed to Donside effluents may also be of direct importance.
Biological magnification of lipid-soluble organic compounds (e.g. PM diterpenoid acids and IB petroleum hydrocarbons) in fish is well documented (Andersson 1987 ) and the toxicity of compounds like diterpenoid acids is often delayed until lipid reserves are utilised (Kruzynski 1979). Such a toxic action may be of key significance to migrating adult Don salmon which cease feeding upon entry into fresh water and rely upon lipid reserves as their major energy source. Storage of toxicants in cellular lipids may occur with resulting disruption of cell function and integrity once energy reserves have been utilised.

A sequential combination of industrial stream (petroleum hydrocarbons, glycols, etc.) and untreated paper mill (diterpenoid acids, benzothiazoles, etc.) effluents combined with the physiological status of adult wild Atlantic salmon produced the hyperbilirubinaemia in experimental fish which is associated with yellow Don salmon. Further chemical and biological characterisation tests are now required to determine the specific chemical agents causing this problem

Post 1987, following the installation of primary effluent treatment plants at two thirds of the paper mills, there was a significant decrease in the annual numbers of wild hyperbilirubinaemic salmon in the River Don. This is probably related to the observation that the concentrations within paper mill effluents of diterpenoid acids, implicated as 'active' haemolytic agents in previous studies, were substantially reduced $\left(400 \mu \mathrm{g} \mathrm{l}^{-1}\right.$ to $\left.<10 \mu \mathrm{gl}^{-1}\right)$ by biological treatment of the effluent. It is hoped that when the installation of an effluent treatment plant is shortly completed at the remaining paper mill, water quality in the River Don will have been returned to levels sufficient to further alleviate or eradicate this problem. However, to fully eradicate this environmental problem the subject of remedying industrial burn effluents also needs to be addressed by the appropriate organisations.

Acknowledgements. We thank staff at the SOAFD Marine Laboratory in Aberdeen, in particular: Miss A. M. Shanks, for statistical analysis; Drs A. E. Ellis and D. E. Wells for comments on the manuscript; and the Director, Professor A. D. Hawkins, for providing facilities. We also thank Dr R. Wilby, Severn Trent Water Ltd for further statistical analyses.

\section{LITERATURE: CITED}

Andersson, T (1987). Sublethal physiological effects of pulp and paper mill effluents on fish. A literature review. National Swedish Environmental Protection Board. US Department of Commerce, National Technical Information Service, Report

Blaxhall, P. C., Daisley, K. W (1973). Routine haematological methods for use with fish blood. J. Fish Biol. 5: 771-781 
Culling, C. F. A. (1974). Handbook of histopathological and histochemical techniques, 3rd edn. Butterworths, London

Everall, N. C., Mitchell, C. G., Robson, J. N. (1989). An epidemiological and toxicological study of haemolytic anaemia in wild Atlantic salmon from the River Don, Aberdeenshire. North East River Purification Board, Scotland

Everall, N. C., Mitchell, C. G., Groman, D. B., Johnston, J. A. A. (1991). Tracing of haematotoxic agents in water with the aid of captive fish: a study with captive adult Atlantic salmon (Salmo salar L.) in the River Don, Aberdeenshire. Dis. aquat. Org. 10: 75-85

Fales, H. M., Jaouni, T. M., Babashak, J. F. (1973). Simple device for preparing etheral diazomethane without resorting to codistillation. Analyt. Chem. 45: 2302-2303

Gay, J., Jeffcoat, R., Dunn, P. J., Hawkins, J. E. (1987). Stormwater contamination at airports and remedial options with particular reference to Stanstead. J. Inst. Wat. Environ. Manage. 1: 253-262

Groman, D. B., Miller, K. (1987). Haemolytic anaemia of wild Atlantic salmon: haematology and chemical pathology. Aquaculture 67: 210-211

Härdig, J., Andersson, T., Bengtsson, B., Forlin, L., Larsson, A. (1988). Long-term effects of bleached kraft mill effluents on red and white blood cell status, ion balance and vertebral structure in fish. Ecotoxicol. environ. Saf. 15: 96-106

Kruzynski, G. M. (1979). Some effects of dehydroabietic acid (DHAA) on hydromineral balance and other physiological parameters in juvenile sockeye salmon, Oncorhynchus nerka. Ph.D thesis, Faculty of Graduate Studies, University of British Columbia

Responsible Subject Editor: G. Peters, Hamburg, Germany
Mattsoff, L., Oikari, A. (1987). Acute hyperbilirubinaemia in rainbow trout (Salmo gairdneri) caused by resin acids. Comp. Biochem. Physiol. 88C: 263-268

Mattsoff, L., Nikinmaa, M. (1988). Dehydroabietic acid (DHAA) does not inhibit bilirubin conjugation in the liver of rainbow trout. Bull. environ. Contam. Toxicol. 41 $894-901$

Nemcsók, J., Benedeczky, I., Boross, L., Aoztalos, B., Orbán, L. (1981). Subcellular localisation of transaminase enzymes in fishes and their significance in the detection of water pollution. Acta Biol. (Szeged) 27: 9-15

Ritsema, R., Cofino, W. P., Frintop, P. C. M., Brinkman, U. A. Th. (1989). Trace-level analysis of phthalate esters in surface waters and suspended matter by means of capillary gas chromatography with electron capture and mass selective detection. Chemosphere 18: 2161-2175

Scotchford, C. A. (1989). A histological investigation of the liver and red blood cells of Atlantic salmon (Salmo salar Linneaus), affected by a pollutant induced haemolytic anaemia in the River Don. M.Sc. thesis, Plymouth Polytechnic, U.K.

Soivio, A., Nikinmaa, M. (1981). The swelling of erythrocytes in relation to the oxygen affinity of the blood of rainbow trout, Salmo gairdneri Richardson. In: Pickering, A. D. (ed.) Stress in fish. Academic Press, London, p. 103-119

Tietz, N. (ed.) (1976). Fundamentals of clinical chemistry. W. B. Saunders, London

Waldock, M. J. (1983). Determination of phthalate esters in samples from the marine environment using gas chromatography mass spectrometry. Chem. Ecol. 1: 261-277

Manuscript first received: October 10, 1991

Revised version accepted: February 7, 1992 